\title{
SOSIALISASI SPORT MASSAGE DAN PENGGUNAAN KINESIO TAPING BAGI ATLET DAN PELATIH PENCAK SILAT
}

\author{
Galih Priyambada $^{1 *}$, Yulia Tri Kusumawati ${ }^{1}$ \\ ${ }^{1}$ Jurusan Pendidikan Olahraga, Fakultas Ilmu Pendidikan, Universitas Muhammadiyah Kalimantan Timur, \\ Samarinda, Indonesia \\ *Penulis Korespodensi: galih031@umkt.ac.id
}

\begin{abstract}
Abstrak
Persiapan sebelum berlatih dan bertanding merupakan hal utama yang harus diperhatikan, Tujuan dari kegiatan Pengabdian Kepada Masyarakat (PKM) ini yaitu untuk memberikan sosialisasi dan pelatihan kepada atlet dan pelatih pencak silat SKOI mengenai pentingnya sport massage dan penggunaan kinesio taping. PKM ini dilakukan dengan langkah observasi awal untuk memunculkan masalah yang ada dan kemudian dikaji untuk diberikan pemecahan masalah tersebut yaitu dengan sosialisasi pelatihan sport massage dan penggunaan kinesio taping pada atlet dan pelatih pencak silat SKOI Kalimantan Timur. Pengabdian ini dilaksanakan di Sekolah Khusus Olahraga Internasional (SKOI) Kalimantan Timur dengan sasaran atlet pencak silat SKOI yang berjumlah 12 orang dan pelatih pencak silat SKOI yang berjumlah dua orang. Berdasarkan hasil pelaksanaan sosialisasi maka dapat diberikan keterangan bahwa terjadi peningkatan pemahaman dan kemampuan sport massage serta penggunaan kinesio taping bagi atlet dan pelatih, hal tersebut dapat dijelaskan berdasarkan umpan balik saat pelaksanaan sosialisasi dan praktik langsung saat sosialisasi.
\end{abstract}

Kata kunci: sosialisasi, sport massage, kinesio taping, atlet, pelatih, pencak silat

\begin{abstract}
Preparation before exercise and compete is the main thing that must be considered, the purpose in this devotion is to provide socialization and training toward athletes and pencak silat's trainers of SKOI related to the importance of sports massage and the use of kinesio taping. This Community service was done with the initial observation step to bring up existing problems and it was studied for given problem solving by the socialization of sports massage training and utilizing of kinesio taping at athletes and trainers of pencak silat in SKOI, East Kalimantan. This devotion is held in the Sekolah Khusus Olahraga Internasional (SKOI) East Kalimantan which consisted of 12 athletes of pencak silat and 2 trainers. Based on the results of the socialization, it concluded that there was increased understanding and capability in sports massage and the utilizing of kinesio taping for athletes and trainers; it could be explained based on feedback during the implementation of socialization and practice directly during the socialization.
\end{abstract}

Keywords: socialization, sport massage, kinesio taping, athletes, trainers, pencak silat's

\section{PENDAHULUAN}

Kalimantan Timur merupakan provinsi Indonesia di pulau Kalimantan yang terbagi oleh beberapa kotamadya dan kabupaten yang ada di Kalimantan Timur. Ibu kota Provinsi Kalimantan Timur terletak di kota Samarinda, serta salah satu kota terbesar di Kalimantan. Samarinda memiliki wilayah seluas 718 $\mathrm{km}^{2}$ dengan kondisi geografi daerah berbukit dengan ketinggian bervariasi dari 10 sampai 200 meter dari permukaan laut. Kota Samarinda dibelah oleh Sungai Mahakam dan menjadi gerbang menuju pedalaman Kalimantan Timur melalui jalur sungai, darat maupun udara.

Samarinda yang menjadi ibu kota provinsi Kalimantan Timur sekaligus menjadi pusat dari beberapa tempat pendidikan, mulai pendidikan formal hingga sekolah khusus dan pelatihan. Sekolah khusus olahraga di Kalimantan Timur yang terletak di Samarinda merupakan Sekolah Khusus Olahraga Internasional (SKOI) di bawah naungan dinas Pendidikan Pemuda dan Olahraga Provinsi Kalimantan Timur. SKOI Kalimantan Timur merupakan sekolahan yang di dalamnya terdapat kekhususan yaitu dalam bidang Olahraga, di mana yang bersekolah di SKOI merupakan atlet terpilih untuk dapat mengikuti peoses pembelajaran dan pelatihan kecabangan olahraga di SKOI Kalimantan Timur.

Cabang olahraga yang ada di SKOI dibina oleh pelatih yang berpengalaman, dan dari beberapa cabang olahraga yang ada di SKOI merupakan olahraga bela diri yang antaranya pencak silat, karate, taekwondo, kempo, dan tarung derajat, dari beberapa olahraga bela 
diri tersebut semuanya memiliki karakteristik tersendiri, dan dari jenis olahraga yang dimaksud yaitu termasuk ke dalam jenis olahraga yang memiliki tingkat resiko cedera tinggi. Melihat dari jenis dan karakteristik olahraga yang memiliki tingkat cedera olahraga tinggi maka penting halnya untuk selalu memperhatikan keselamatan dalam berlatih dan bertanding.

Persiapan sebelum berlatih dan bertanding merupakan hal utama yang harus diperhatikan. Menjadi prioritas penting yaitu upaya keselamatan berlatih dan bertanding seperti halnya pemanasan yang tepat dan antisipasi cedera saat bertanding seperti pemberian shakeing pada bagian otot tertentu. Di samping pemberian treatment tersebut upaya lain yang bias diberikan yaitu dengan pemasangan kinesio taping pada bagian otot atau sendi yang beresiko cedera. Tidak semua atlet atau pelatih menguasai teknik tersebut, dalam hal ini yaitu di mana pemberian treatment yang dimaksud yaitu sport massage dengan tujuan antisipasi terhadap cedera yang dikombinasikan dengan pemberian kinesio taping pada bagian otot tertantu.

Olahraga beladiri dalam hal ini akan mengarah pada cabang olahraga bela diri pencak silat yang ada di SKOI Kalimantan Timur. Olahraga bela diri pencak silat merupakan cabang olahraga asli Indonesia yang sudah banyak menorehkan prestasi baik dalam kejuaraan Nasional hingga Internasional. Kombinasi gerakan dalam pencak silat jika tidak dilakukan dengan penuh kehati-hatian maka akan sangat beresiko terhadap cedera. Dengan sosialisasi sport massage dan kinesio taping peda atlet diharapkan akan memberikan pemahaman pentingnya treatment tersebut, sehingga dalam menjalani latihan dan pertandingan tidak lagi salah dalam upaya penanganan.

Massage berasal dari kata massein dalam Bahasa Yunani yang berarti menggosok, diartikan menekan dengan lembut, berasal dari bahasa Arab mash, dan menurut bahasa Perancis masser yang berarti mengeramasi Priyonoadi (2008: 5). Massage mempunyai pengaruh terapeutik umum dan fisiologis, kondidi pantang massage yaitu ketika terjadi patah atau retak tulang, dislokasi, peradangan, daging sendi, daging tumbuh, saat demam, disentri, dan ibu mengandung (Fondy, 2012: 58).

Pengaruh tersebut dapat menguatkan otot melalui gerakan gerakan yang tetap dan berirama, merangsang sirkulasi cairan-cairan tubuh seperti darah dan limfa, merangsang keadaan supel melalui manipulasi dari jaringan tulang, mengatasi problemproblem muskuloskeletal seperti sendi yang dapat dikurangi dengan meningkatkan keadaan supel dari otot, sistem saraf dapat bekerja lebih harmonis melalui stimulasi dan relaksasi, organ-organ dalam terstimulasi dan fungsinya lebih baik sehingga dapat merangsang secara langsung kelenjar-kelenjar hormon, dan menyebabkan kekakuan otot dapat dikurangi atau dihindari.
Masase merupakan teknik manipulasi jaringan lunak melalui tekanan dan gerakan menggosok, memijat, menekan, bergulir, menampar, dan mengetuk (Park, 2017: 789). Teknik ini dapat dilakukan pada seluruh tubuh maupun pada bagian tertentu, seperti punggung, kaki, dan tangan. Masase olahraga (sportmassage) memiliki aplikasi pokok berupa teknik gerakan seperti effleurage, petrissage, vibration. menguraikan beberapa pengertian serta teknik dasar sekaligus tehnik yang akan menjadi bahan dalam penelitian peneliti.

Sport massage dalam kaitannya dengan olahraga dan aktifitas fisik lainnya yaitu sama-sama dalam lingkup olahraga di mana olahraga atau aktifitas fisik merupakan bentuk kegiatan atau aktifitas geraknya, sedangkan sport massage merupakan upaya penanganan dari akibat kelelahan dari olahraga aktifitas fisik lainnya. Aktifitas olahraga dan aktifitas fisik akan membuat detak jantung berdebar berbeda dengan kondisi istirahat. Sport massage dilakukan dapat memberikan sumbangan pada pada pemanasan fisik (Arabaci, 2008).

Kondisi tubuh akibat olahraga merupakan kondisi yang pada kenyataannya dapat ditanggulangi dengan beberapa upaya, diantaranya dengan penanganan massage dan kinesio taping. Kinesio Taping adalah sebuah metode atau cara dalam memfasilitasi kerja otot untuk meminimalkan resiko dari cedera dengan menggunakan perekat elastis yang dapat ditarik dengan tarikan yang bervariasi dari panjang sebenarnya.. Kinesio Taping memberikan efek : (1). Meningkatkan sirkulasi lokal (2). Mengurangi oedema lokal (3). Meningkatkan peredarah darah (4). Meberikan stimulasi pada kulit, otot, atau struktur fascia (5). Memfasilitasi input ke sistem saraf pusat (6). Membatasi lingkup gerak sendi (Iglesias, 2009).

Studi pendahuluan yang dilakukan kepada pelatih dan atlet SKOI Kalimantan Timur, ditemukan beberapa alasan terkait pemahaman tentang sport massage dan optimalisasi kinesio taping. Yang mana selama ini para pelatih dan atlet dalam memahami sport massage sering kali kurang tepat di mana anggapan tersebut sering diartikan bahwa sport massage merupakan penanganan terhadap orang yang sedang cedera. Pada hakikatnya sport massage ialah suatu bentuk penanganan pada kondisi seseorang yang sedang sehat.

Pelatih dan atlet SKOI Kalimantan Timur dalam pemahaman dan penggunaan taping masih kurang optimal. Hal tersebut berdasarkan diskusi dan observasi awal yang dilakukan sering dijumpai para atlet dalam menggunakan taping kurang tepat. Sehingga aplikasi dan tujuan dari pemberian taping kurang menjadi efektif. Berdasarkan studi pendahuluan mengenai masalah yang ada maka dianggap perlu untuk diberikan sosialisasi terkait sport massage dan kinesio taping. Bagi pelatih dan atlet pencak silat SKOI Kalimantan Timur

\section{METODE PELAKSANAAN}


Metode kegiatan dalam pengabdian ini yaitu menggunakan metode sosialisasi yang diberikan kepada atlet pencak silat SKOI Kalimantan Timur adapun sosialisasi yang digunakan yaitu sport massage dan penggunaan kinesio taping. Pengabdian melalui sosialisasi sport massage dan penggunaan kinesio taping terhadap atlet pencak silat SKOI Kalimantan Timur menggunakan sistem pertemuan class room yang dirancang selama dua kali pertemuan dengan memberikan materi dan pemahaman kepada atlet pencak silat SKOI Kalimantan Timur.

Selanjutnya bagi pelatih dilakukan dengan metode sosialisasi dan praktik langsung tentang teknik sport massage dan penggunaan kinesio taping serta pemahaman mengenai gambaran berwirausaha melalui sport massage dan penggunaan kinesio taping adapun kegiatan dilakukan selama dua kali pertemuan dan dilakukan di dalam kelas (class room).

Proses sosialisasi sport massage dan penggunaan kinesio taping pada atlet pencak silat SKIO Kalimantan Timur dengan langkah awal yaitu observasi awal sebagai study pendahuluan untuk mendapatkan gambaran mengenai kegiatan yang dimaksud yang selanjutnya menyusun materi yang akan dijadikan bahan sosialisasi dan yang selanjutnya yaitu pelaksanaan sosialisasi dengan maksud untuk memberikan gambaran tentang bahaya terhadap suatu gerakan yang kurang tepat serta kurangnya persiapan dan treatment sebagai antisipasi terhadap cedera olahraga. Pada hal ini sport massage dan penggunaan kinesio taping menjadi sebuah treatment yang akan disampaikan dalam kegiatan pengabdian atau sosialisasi pada atlet pencak silat SKOI Kalimantan Timur dengan jumlah atlet pencak silat 12 orang atlet, yang berlokasi di SKOI Palaran Kota Samarinda Kalimantan Timur.

Proses kegiatan sosialisasi untuk pelatih tentang sport massage dan kinesio taping dan potensi wirausaha dilakukan dengan jumlah pertemuan yaitu dua kali pertemuan yang di dalamnya akan dipaparkan beberapa materi tentang pelaksanaan sport massage dan kinesio taping serta keuntungan dalam mempelajari sport massage dan kinesio taping.

\section{RANCANGAN EVALUSAI}

Evaluasi yang akan dilakukan yaitu dengan memberikan pemahaman terkait pentingnya sport massage dan penggunaan kinesio taping adapun strategi yang dilakukan yaitu dengan memberikan tes di akhir sosialisasi, kemudian untuk pelatih pencak diberikan tes tambahan yaitu berupa praktik sport massage dan pemasangan kinesio taping yang hasilnya akan dijadikan sebagai tolok ukur ketercapaian dari tujuan sosialisasi pentingnya sport massage dan penggunaan kinesio taping.

\section{HASIL DAN PEMBAHASAN}

Kegiatan pengabdian kepada masyarakat dilaksanakan dalam rangka pemberian pemahaman terkait sport massage dan kinesio taping pada atlet dan secara khusus pelatih pencak silat SKOI Kaltim. Adapun metode pelaksanaan yang akan dilakukan oleh tim pengusul adalah :

Tabel 1. Sosialisasi sport massage dan penggunaan kinesio taping bagi atlet

\begin{tabular}{|c|c|}
\hline $\begin{array}{l}\text { Tujuan } \\
\text { kegiatan }\end{array}$ & $\begin{array}{l}\text { 1. Memberikan pengetahuan tentang } \\
\text { fungsi dan manfaat sport massage } \\
\text { dan kinesio taping. } \\
\text { 2. Mensosialisasikan manfaat sport } \\
\text { massage terhadap upaya } \\
\text { pencegahan cedera olahraga. }\end{array}$ \\
\hline Isi kegiatan & $\begin{array}{l}\text { Sosialisasi manfaat dan fungsi sport } \\
\text { massage dan penggunaan kinesio } \\
\text { taping bagi atlet pencak silat SKOI } \\
\text { Kaltim. }\end{array}$ \\
\hline Sasaran & $\begin{array}{l}\text { Atlet pencak silat Sekolah Khusus } \\
\text { Olahraga Internasional Kalimantan } \\
\text { Timur }\end{array}$ \\
\hline Strategi & $\begin{array}{l}\text { Ceramah, diskusi dan bimbingan cara } \\
\text { meminimalkan resiko cedera melalui } \\
\text { sport massage serta penggunaan } \\
\text { kinesio taping. }\end{array}$ \\
\hline Evaluasi & $\begin{array}{l}\text { Memberikan umpan balik berupa } \\
\text { pertanyaan mendasar terkait sport } \\
\text { massage dan kinesio taping. }\end{array}$ \\
\hline Capaian & $\begin{array}{l}\text { Meningkatnya pengetahuan peserta } \\
\text { tentang bahaya cedera serta upaya } \\
\text { meminimalkan cedera dan } \\
\text { pemahaman mengenai sport massage } \\
\text { dan kinesio taping. }\end{array}$ \\
\hline
\end{tabular}

\begin{tabular}{|c|c|}
\hline $\begin{array}{l}\text { Tujuan } \\
\text { kegiatan }\end{array}$ & $\begin{array}{l}\text { 1. Memberikan pemahaman bentuk } \\
\text { terapi pasca cedera olahraga } \\
\text { menggunakan kinesio taping. } \\
\text { 2. Gambaran peluang usaha melalui } \\
\text { sport massage dan kinesio taping }\end{array}$ \\
\hline Isi kegiatan & $\begin{array}{l}\text { Sosialisasi dan pelatihan serta } \\
\text { gambaran peluang usaha dari } \\
\text { pemanfaatan sport massage dan } \\
\text { penggunaan kinesio taping pada } \\
\text { pelatih pencak silat SKOI Kaltim. }\end{array}$ \\
\hline Sasaran & $\begin{array}{l}\text { Pelatih pencak silat Sekolah Khusus } \\
\text { Olahraga Internasional (SKOI) } \\
\text { Kalimantan Timur }\end{array}$ \\
\hline Strategi & $\begin{array}{l}\text { Ceramah, diskusi, demonstrasi dan } \\
\text { pelatihan. }\end{array}$ \\
\hline Evaluasi & $\begin{array}{l}\text { Menguji peserta tentang } \\
\text { pengetahuan, serta keterampilan } \\
\text { dalam mempraktikan sport massage } \\
\text { dan penggunaan kinesio taping. }\end{array}$ \\
\hline Capaian & $\begin{array}{l}\text { Meningkatnya pengetahuan dan } \\
\text { keterampilan pelatih pencak silat } \\
\text { dalam pelaksanaan sport massage } \\
\text { dan penggunaan kinesio taping serta } \\
\text { dalam upaya penanganan pada atlet } \\
\text { dan pemahaman terkait peluang } \\
\text { wirausaha melalui kegiatan sport } \\
\text { massage dan kinesio taping. }\end{array}$ \\
\hline
\end{tabular}




\section{KESIMPULAN}

Berdasarkan paparan hasil yang disajikan maka dapat ditarik sebuah kesimpulan bahwa atlet dan pelatih pencak silat SKOI Kalimantan Timur setelah mengikuti sosialisasi dan pelatihan dapat dikatakan meningkat dalam hal pemahaman dan kemampuan dasar terkait sport massage dan penggunaan taping. Hal tersebut didilihat dengan tes dan evaluasi sebelum dan sesudah sosialisasi.

\section{IMPLIKASI}

Dari hasil pengabdian pada masyarakat dengan tema sosialisasi sport massage dan penggunaan kinesio taping pada atlet dan pelatih pencak silat SKOI Kalimantan Timur maka implikasinya adalah sebagai berikut: Menunjukkan bahwa pemahaman serta kemampuan atlet dan pelatih dalam hal sport massage dan penggunaan kinesio taping mengalami peningkatan, hal tersebut dilihat dari evaluasi yang diberikan kepada atlet dan pelatih pencak silat SKOI Kalimantan Timur. Para atlet dan pelatih harus lebih memahami resiko cedera dan meminimalkannya dengan berbagai strategi baik sport massage dan penggunaan kinesio taping dengan baik dan benar.

\section{DOKUMENTASI PELAKSANAAN}

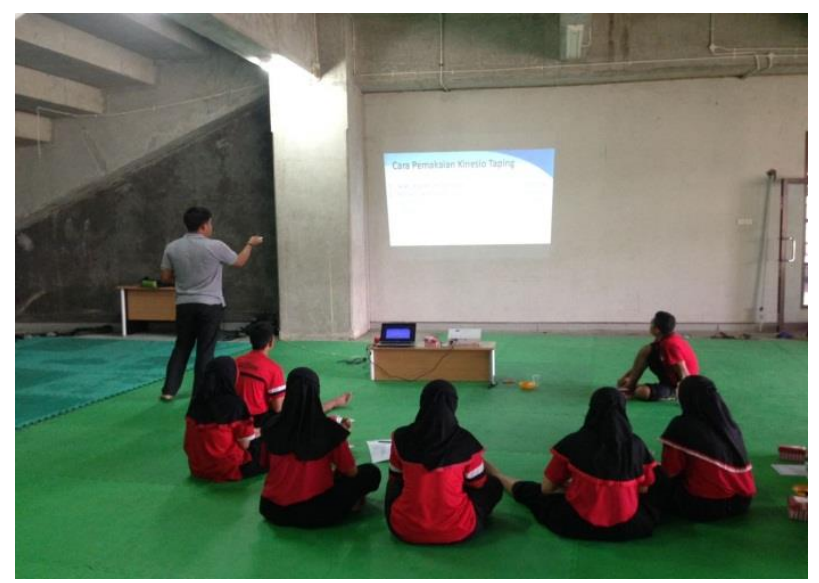

Gambar 1. Pelaksanaan Sosialisasi Bagi Atlet Dan Pelatih Pencak Silat SKOI Kalimantan Timur

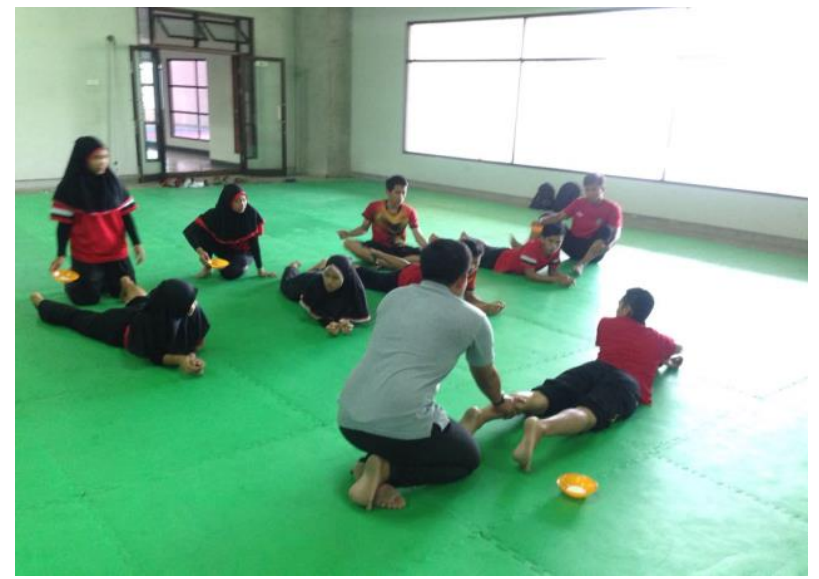

Gambar 2. Pelaksanaan Pelatihan Bersama Atlet Dan Pelatih Pencak Silat SKOI Kalimantan Timur

\section{DAFTAR PUSTAKA}

Arabaci.R. (2008). Acute Effects Of Pre-Event Lower Limb Massage On Explosive And High Speed Motor Capacities And Flexibility. Journal of Sports Science and Me dicine. Vol. 7,Hlm. 549-555.

Fondy, T. (2012). Merawat dan Mereposisi Cedera Tubuh. Banten: Pustaka Tumbar.

Iglesias, J.G., Cesar, F.D.L.P., Cleland, J., Huijbregts, P., dan Vega, M.D.R.G. 2009. Short-Term Effect Of Cervical Kinesio Taping On Pain and Cervical Range Of Motion in Patient With Acute Whiplash Injury: A Randomized Clinical Trial. Journal of Orthopaedic \& Sports Physical Therapy, 39(7): 518-519.

Park, J., Shim, J., Kim, S., Namgung, S., Ku, I., Cho, M., . . Roh, H. (2017). Application of massage for ankle joint flexibility and balance. Journal of physical therapy science, 29(5), 789-792.

Priyonoadi, B. (2008). Sport Massage (Masase Olahrga). Yogyakarta: FIK UNY. 